\title{
Identification of sand flies (Diptera: Psychodidae) and blood meal sources in periurban areas of Ji-Paraná municipality, Western Brazilian Amazon
}

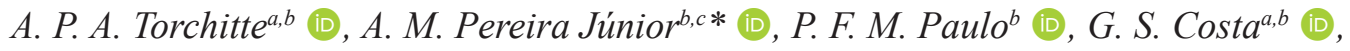 \\ T. S. Castro ${ }^{b}$ (D), R. G. M. Ferreira (ID) and J. F. Medeiros $^{b, c}$ (iD \\ aPrograma de Pós-graduação em Biologia Experimental, Fundação Universidade Federal de Rondônia, BR 364, Km 9.5, \\ CEP 76801-059, Porto Velho, RO, Brasil \\ bLaboratório de Entomologia, Fundação Oswaldo Cruz - Fiocruz Rondônia, Rua da Beira, 7671, CEP 76812-245, \\ Porto Velho, RO, Brasil \\ 'Instituto Nacional de Epidemiologia da Amazônia Ocidental - INCT-EpiAMO, Rua da Beira, 7671, CEP 76812-245, \\ Porto Velho, RO, Brasil \\ dLaboratório de Epidemiologia Genética, Fundação Oswaldo Cruz - Fiocruz Rondônia, Rua da Beira, 7671, \\ CEP 76812-245, Porto Velho, RO, Brasil \\ *e-mail: junior.ampj@gmail.com
}

Received: September 2, 2019 - Accepted: November 6, 2019 - Distributed: February 28, 2021

(With 1 figure)

Leishmaniases is a disease caused by Leishmania protozoans which are transmitted to vertebrates by the bite of female sand flies. Epidemiological surveillance depends on the identification of vector species and their reservoirs, and identifying sand fly blood meal sources can be an effective means of identifying potential reservoirs in the Leishmaniasis transmission cycle (Roque and Jansen, 2014). In Rondônia State, approximately 1,000 new cases of cutaneous leishmaniasis (CL) occur annually (DATASUS, 2018). In Ji-Paraná municipality, which is located in the eastern mesoregion of Rondônia (see Figure 1), 418 cases of CL have been registered since 2007 (DATASUS, 2018); in spite of this, there is not much information about Leishmania infection, sand fly vectors and, their blood sources that occur there (Biancardi et al., 1982). The aims of our study was to verify these insects and possible blood meals in Ji-Paraná municipality.

Sand fly collections were made using light traps that were set for three consecutive nights in small forest fragments near eight periurban areas (see Figure 1C). Two collections were performed: one in November of 2017 and another in November of 2018. Males and females (head and last segments) were slide-mounted and morphologically identified (Galati, 2018).

In order to screen for the presence of Leishmania DNA, the thoraxes of non-engorged females were separated into pools and subjected to polymerase chain reaction assays using primers targeting $k$ DNA (Pereira Júnior et al., 2019). The Le. amazonensis strain (IFLA/BR/1967/PH8) was used as the positive control and ultrapure water was used as the negative control. Blood meal sources were identified by submitting the thoraxes of engorged females to DNA extraction using the phenol/chloroform protocol; to avoid sample contamination, two samples containing a female with no blood present in the gut and one sample containing DNA-free water were used as negative controls.
Extracted DNA was subjected to PCR assays targeting the cytb mitochondrial region (Pereira Júnior et al., 2019).

A total of 1,331 sand flies comprising 28 species were identified (as shown in Table 1). The most abundant species were Psychodopygus davisi (491 individuals, 36.9\%) and Ps. hirsutus hirsutus (391 individuals, 29.4\%) (see Figure 1C). In Rondônia, Ps. davisi generally occurs in high abundance (Gil et al., 2003; Pereira Júnior et al., 2019). Specimens of both species have been found carrying Leishmania naiffi promastigotes (Gil et al., 2003); however, none of the 80 pools in our study exhibited the presence of Leishmania DNA.

Blood meal analysis revealed the DNA of Homo sapiens in one Ps. davisi female and four Ps. hirsutus hirsutus females, while DNA of the wild vertebrates Alouatta seniculus and Dasypus sabanicola was present in the gut of two Ps. hirsutus hirsutus females (as shown in Table 2). Dasypus sabanicola is not found in Brazil (Abba and Superina, 2010) and probably the DNA sequence could be another species of Dasypus genera with distribution in the Brazilian Amazon as Dasypus novemcinctus or Dasypus kappleri.

The finding that Ps. hirsutus hirsutus and Ps. davisi feed on wild vertebrates may help to improve our understanding of the hematophagous habits of these species as well as our understanding of the Leishmania transmission cycle in this region. The presence of $H$. sapiens DNA in engorged sand flies combined with the high abundance of these species indicates that humans have been exposed to bites from potential vectors in four of the eight localities in Ji-Paraná. Recently, Pereira Júnior et al. (2019) identified the DNA of humans and anteaters in sand flies from forest and peridomicile areas in Rondônia. Our results corroborate their findings and demonstrate that sand flies use a variety of blood meal sources, including humans, in Ji-Paraná; these findings increase our epidemiological knowledge of $\mathrm{CL}$ in the region. 


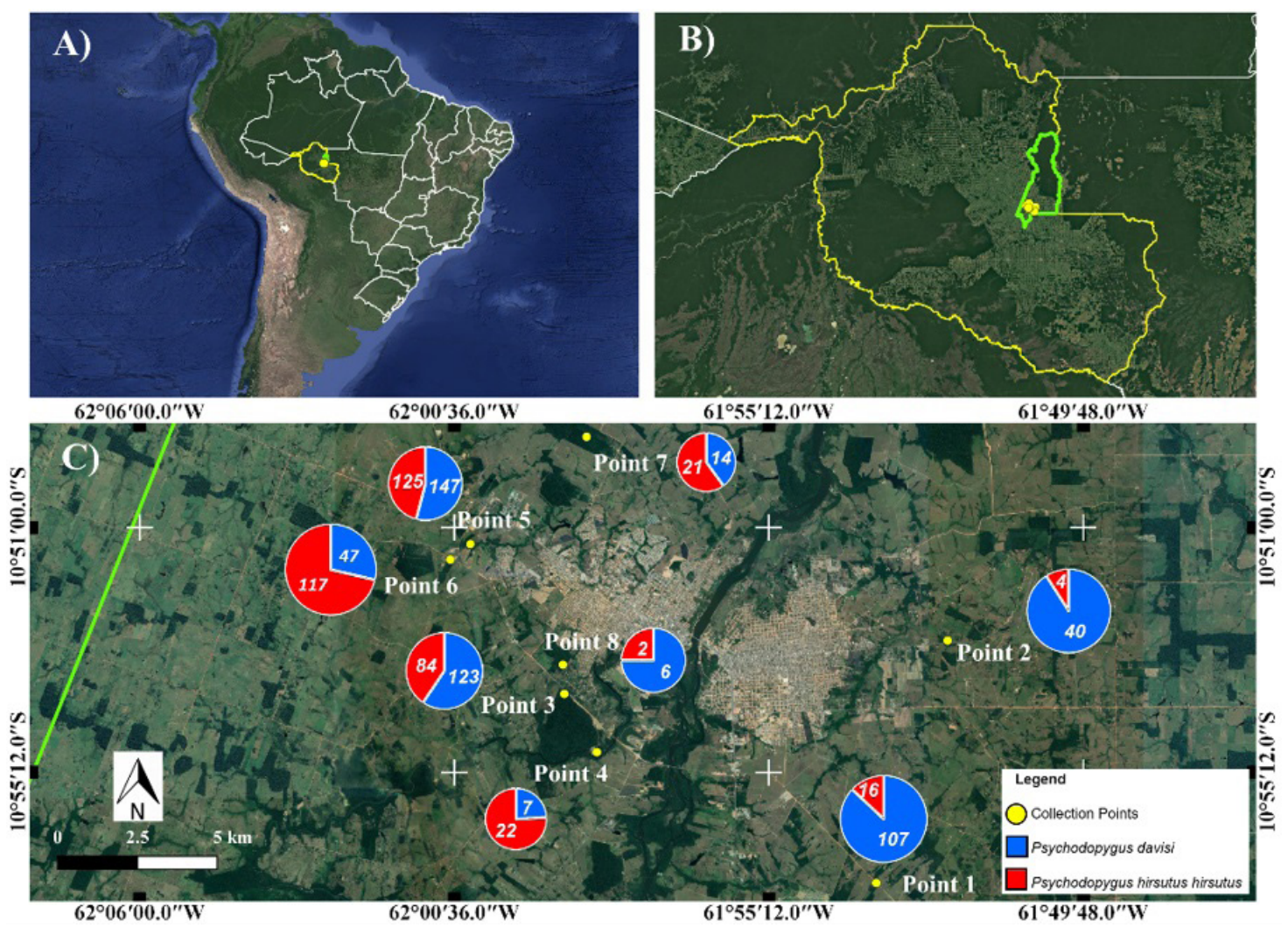

Figure 1. (A) South America map with Brazil Map delimited by white line indicating the states limits and in yellow the limits of the Rondônia State; (B) Map of Rondônia state in a large view (yellow line) and in green line indicating the limits of Ji-Paraná municipality; (C) Collection points distributed among periurban areas of Ji-Paraná with the number of Psychodopygus davisi (blue) and Ps. hirsutus hirsutus individuals (red) given for each location.

Table 1. Sand fly fauna collected at eight points in Ji-Paraná municipality in November of 2017 and 2018. Numbers in parentheses represent engorged females.

\begin{tabular}{|c|c|c|c|c|c|c|c|c|c|c|}
\hline Species & $\begin{array}{c}\text { P1 } \\
/ \hat{O}^{\hat{2}}\end{array}$ & $\begin{array}{c}\mathbf{P 2} \\
q / \hat{O}\end{array}$ & $\begin{array}{c}\mathbf{P 3} \\
+1 \hat{S}^{\wedge}\end{array}$ & $\begin{array}{c}\text { P4 } \\
\text { का }\end{array}$ & $\begin{array}{l}\text { P5 } \\
\text { कारी } \\
\end{array}$ & $\begin{array}{l}\text { P6 } \\
q / \hat{o} \\
\end{array}$ & $\begin{array}{c}\text { P7 } \\
q / \hat{0} \\
\end{array}$ & $\begin{array}{l}\text { P8 } \\
q / \hat{0} \\
\end{array}$ & Total & $\%$ \\
\hline Bichromomyia flaviscutellata & $5 / 2$ & $1 / 0$ & $1 / 5$ & - & $0 / 2$ & $0 / 2$ & $2 / 4$ & - & 24 & 1.8 \\
\hline Brumptomyia brumpti & - & - & $4 / 7$ & $1 / 3$ & - & - & - & - & 15 & 1.1 \\
\hline Evandromyia saulensis & $2 / 0$ & - & $45 / 28$ & $5 / 1$ & $1 / 0$ & $2 / 0$ & $5 / 0$ & - & 89 & 6.7 \\
\hline Evandromyia walkeri & $2 / 1$ & $1 / 0$ & $8 / 7$ & - & - & - & - & - & 19 & 1.4 \\
\hline Lutzomyia sherlocki & - & $1 / 0$ & $1 / 0$ & - & - & $3 / 0$ & - & - & 5 & 0.4 \\
\hline Microppygomyia rorotaensis & - & - & - & - & $1 / 0$ & $0 / 2$ & $2 / 2$ & - & 7 & 0.5 \\
\hline Micropygomyia villelai & $0 / 3$ & - & - & - & - & $2 / 0$ & $2 / 0$ & - & 7 & 0.5 \\
\hline Migonemyia migonei & - & $1 / 0$ & $1 / 0$ & - & - & - & - & - & 2 & 0.2 \\
\hline Nyssomyia antunesi & $8 / 0$ & $1 / 3$ & $24 / 5$ & $2 / 0$ & $4 / 0$ & $7 / 0$ & $12 / 3$ & - & 69 & 5.2 \\
\hline Nyssomyia whitmani & $1 / 0$ & $0 / 1$ & $2 / 2$ & - & $1 / 2$ & $4 / 1$ & $10 / 3$ & $0 / 1$ & 28 & 2.1 \\
\hline Pintomyia nevesi & $5 / 6$ & $2 / 5$ & $2 / 1$ & - & - & $2 / 0$ & - & $2 / 3$ & 28 & 2.1 \\
\hline Pintomyia serrana & $0 / 3$ & - & $1 / 0$ & - & - & $1 / 0$ & - & - & 5 & 0.4 \\
\hline Psathyromyia campelli & - & - & - & - & - & - & $1 / 0$ & - & 1 & 0.1 \\
\hline Psathyromyia dendrophyla & - & - & $2 / 0$ & - & - & - & - & - & 2 & 0.2 \\
\hline Psathyromyia hermanlenti & - & - & - & $0 / 1$ & $1 / 0$ & $0 / 3$ & - & - & 5 & 0.4 \\
\hline Psathyromyia lutziana & $1 / 0$ & - & $1 / 0$ & - & - & - & $0 / 1$ & - & 3 & 0.2 \\
\hline Psathyromyia runoides & $0 / 1$ & - & $0 / 1$ & - & - & - & - & - & 2 & 0.2 \\
\hline Psychodopygus ayrozai & - & - & $1 / 0$ & - & - & - & - & - & 1 & 0.1 \\
\hline Psychodopygus c. carrerai & - & $4 / 4$ & $5 / 1$ & $2 / 1$ & $5 / 0$ & $9 / 18$ & $5 / 3$ & - & 57 & 4.3 \\
\hline
\end{tabular}


Table 1. Continued...

\begin{tabular}{|c|c|c|c|c|c|c|c|c|c|c|}
\hline Species & $\frac{\text { P1 }}{q / O^{\lambda}}$ & $\frac{\text { P2 }}{+/ \delta}$ & $\frac{\mathbf{P 3}}{q / ठ^{\wedge}}$ & $\frac{\text { P4 }}{+/ \delta^{\lambda}}$ & $\frac{\text { P5 }}{+/ \hat{\zeta}}$ & $\frac{\mathbf{P 6}}{+/ \delta^{\lambda}}$ & $\begin{array}{c}\text { P7 } \\
\text { का }\end{array}$ & $\frac{\text { P8 }}{q / \delta^{\lambda}}$ & Total & $\%$ \\
\hline Psychodopygus chagasi & - & $1 / 0$ & $3 / 0$ & $3 / 0$ & $1 / 0$ & - & $8 / 0$ & - & 16 & 1.2 \\
\hline Psychodopygus claustrei & $0 / 4$ & $0 / 1$ & $1 / 6$ & $0 / 1$ & $0 / 4$ & $0 / 3$ & - & $0 / 1$ & 21 & 1.6 \\
\hline Psychodopygus complexus & - & - & $0 / 1$ & - & $0 / 2$ & - & $1 / 16$ & - & 20 & 1.5 \\
\hline Psychodopygus davisi & $25 / 82$ & $14 / 26$ & $38 / 85$ & $4 / 3$ & $94(1) / 53$ & $19 / 28$ & $4 / 10$ & $4 / 2$ & 491 & 36.9 \\
\hline Psychodopygus geniculatus & - & - & - & - & $0 / 1$ & $2 / 3$ & - & - & 6 & 0.5 \\
\hline Psychodopygus h. hirsutus & $6 / 10$ & $2 / 2$ & $49 / 35$ & $8(1) / 14$ & $103 / 22$ & $65(3) / 52$ & $15 / 6$ & $2 / 0$ & 391 & 29.4 \\
\hline Sciopemyia servulolimai & - & - & - & - & - & - & $1 / 1$ & - & 2 & 0.2 \\
\hline Sciopemyia sordellii & - & - & - & - & - & $0 / 1$ & $8 / 2$ & - & 11 & 0.8 \\
\hline Trichophoromyia clitella & - & $0 / 1$ & $0 / 2$ & - & - & $0 / 1$ & - & - & 4 & 0.3 \\
\hline Total & 167 & 71 & 375 & 49 & 297 & 230 & 127 & 15 & 1,331 & 100 \\
\hline
\end{tabular}

Table 2. Vertebrate species identified from sand fly females collected in Ji-Paraná municipality.

\begin{tabular}{lllccccc}
\hline \multicolumn{1}{c}{$\begin{array}{c}\text { Sand fly } \\
\text { species }\end{array}$} & \multicolumn{1}{c}{ Blood Meal } & Accession & Location & $\begin{array}{c}\text { Identity } \\
(\%)\end{array}$ & $\begin{array}{c}\text { Total } \\
\text { score }\end{array}$ & $\begin{array}{c}\text { Query } \\
\text { cover (\%) }\end{array}$ & E-value \\
\hline Ps. hirsutus & Dasypus sabanicola & KT818545.1 & Point 3 & 95.74 & 448 & 79 & $1 \mathrm{E}-121$ \\
Ps. hirsutus & Homo sapiens & KX697544.1 & Point 3 & 99.01 & 538 & 90 & $5 \mathrm{E}-149$ \\
Ps. hirsutus & Homo sapiens & LCO88150.1 & Point 4 & 98.27 & 507 & 89 & $2 \mathrm{E}-139$ \\
Ps. davisi & Homo sapiens & KX697544.1 & Point 5 & 96.58 & 477 & 85 & $1 \mathrm{E}+130$ \\
Ps. hirsutus & Homo sapiens & LCO88148.1 & Point 6 & 97.82 & 473 & 84 & $2 \mathrm{E}-129$ \\
Ps. hirsutus & Homo sapiens & MH981639.1 & Point 6 & 98.36 & 532 & 86 & $5 \mathrm{E}-147$ \\
Ps. hirsutus & Alouatta seniculus & KR902387.1 & Point 6 & 96.45 & 507 & 99 & $1 \mathrm{E}-139$ \\
\hline
\end{tabular}

\section{References}

ABBA, A.M. and SUPERINA, M., 2010. The 2009/2010 Armadillo Red List Assessment. Edentata, vol. 11, no. 2, pp. 135-184. http:// dx.doi.org/10.5537/020.011.0203.

BIANCARDI, C.B., ARIAS, J.R., FREITAS, R.A. and CASTELLON, E.G., 1982. The known geographical distribution of sand flies in the state of Rondonia, Brazil (Diptera: psychodidae). Acta Amazonica, vol. 12, no. 1, pp. 167-179. http://dx.doi.org/10.1590/180943921982121167.

\section{DEPARTAMENTO DE INFORMÁTICA DO SUS - DATASUS.} Sistema de Informações de Agravos de Notificação, 2018 [viewed 18 December 2018]. Epidemiológicas e Morbidade: Leishmaniose Tegumentar Americana [online]. Brasília: Ministério da Saúde. Available from: http://www2.datasus.gov.br/DATASUS/index.ph $\mathrm{p}$ ?area $=0203 \& \mathrm{id}=29892200 \& \mathrm{VObj}=\mathrm{http} / /$ tabnet.datasus.gov.br/ cgi/deftohtm.exe?sinannet/cnv/lta

GALATI, E.A.B., 2018. Phlebotominae (Diptera, Psychodidae): classification, morphology and terminology of adults and identification of American taxa. In: E.F. RANGEL and J.J. SHAW, eds. Brazilian sand flies: biology, taxonomy, medical importance and control. Gewerbestrasse: Springer, pp. 9-212.

GIL, L.H.S., BASANO, S.A., SOUZA, A.A., SILVA, M.G.S., BARATA, I.R., ISHIKAWA, E.A., CAMARGO, L.M.A. and SHAW, J.J., 2003. Recent observations on the sand fly (Diptera: Psychodidae) Fauna of the State of Rondônia, Western Amazônia, Brazil: the importance of Psychodopygus davisi as a vector of zoonotic cutaneous leishmaniasis. Memórias do Instituto Oswaldo Cruz, vol. 98, no. 6, pp. 751-755. http://dx.doi.org/10.1590/ S0074-02762003000600007. PMid:14595450.

PEREIRA JÚNIOR, A.M., SOUZA, A.B.N., CASTRO, T.S., SILVA, M.S., PAULO, P.F.M., FERREIRA, G.E.M. and MEDEIROS, J.F., 2019. Diversity, natural infection and blood meal sources of phlebotomine sandflies (Diptera, Psychodidae) in the Western Brazilian Amazon. Memórias do Instituto Oswaldo Cruz, vol. 114, pp. e190170. http:// dx.doi.org/10.1590/0074-02760190170. PMid:31365633.

ROQUE, A.L.R. and JANSEN, A.M., 2014. Wild and Synanthropic Reservoirs of Leishmania Species in the Americas. International Journal for Parasitology: Parasites and Wildlife, vol. 3, no. 3, pp. 251-262. http://dx.doi.org/10.1016/j.ijppaw.2014.08.004. PMid:25426421. 